\title{
Resveratrol potentiates effects of simvastatin on inhibition of rat ovarian theca-interstitial cells steroidogenesis
}

\author{
Israel Ortega ${ }^{1,2}$, Jesus A Villanueva ${ }^{1}$, Donna H Wong ${ }^{1}$, Amanda B Cress ${ }^{1}$, Anna Sokalska ${ }^{1,3,4}$, Scott D Stanley ${ }^{5}$
} and Antoni J Duleba ${ }^{1 *}$

\begin{abstract}
Background: Polycystic ovary syndrome (PCOS) is characterized by ovarian enlargement, hyperplastic theca compartment and increased androgen production due to, at least in part, excessive expression of several key genes involved in steroidogenesis. Previously, our group has demonstrated that simvastatin, competitive inhibitor of 3-hydroxy-3-methyl-glutaryl-CoA reductase (HMG-CoA reductase), a rate-limiting step of the mevalonate pathway, reduces rat-theca interstitial cell steroidogenesis by inhibiting Cyp17a1 gene expression, the key enzyme of the androgen biosynthesis pathway. Recently, we demonstrated that resveratrol, a bioflavonoid abundant in red grapes, decreases rat theca-interstitial cell steroidogenesis and this suppressive effect is mediated through mechanisms independent of the mevalonate pathway. The present study evaluated the effect of combining simvastatin and resveratrol treatments on rat theca-interstitial cell steroidogenesis.
\end{abstract}

Methods: Rat theca-interstitial cells isolated from 30 day-old female rats were cultured for up to $48 \mathrm{~h}$ with or without simvastatin $(1 \mu \mathrm{M})$ and/or resveratrol $(3-10 \mu \mathrm{M})$. Steroidogenic enzymes gene expression was evaluated by quantitative real time PCR and steroid levels were measured by liquid chromatography-mass spectrometry. Comparisons between groups were performed using ANOVA and Tukey test.

Results: Resveratrol potentiated inhibitory effects of simvastatin on androstenedione and androsterone production in theca-interstitial cells. This suppressive effect correlated with profound inhibition in Cyp17a1 mRNA expression in the presence of a combination of resveratrol and simvastatin.

Conclusions: The present findings indicate that resveratrol potentiates the simvastatin-induced inhibitory effect on theca-interstitial cell androgen production, raising the possibility of development of novel treatments of PCOS.

Keywords: Androgens, CYP17A1, Ovarian theca-interstitial cells, Resveratrol, Simvastatin, Steroidogenesis

\section{Background}

Theca-interstitial cells play a prominent role in folliculogenesis, controlling follicle growth and atresia, providing mechanical support for ovarian follicles and regulating ovarian steroidogenesis [1]. Differentiation of thecainterstitial cells from steroidogenically inactive cells into androgen-producing cells occurs during preantral stages of follicular development and involves expression of steroid pathway biosynthetic genes. Under pathological conditions

\footnotetext{
*Correspondence: aduleba@ucsd.edu

'Department of Obstetrics and Gynecology, School of Medicine, University of California, Davis, CA 95616, USA

Full list of author information is available at the end of the article
}

such as polycystic ovary syndrome (PCOS), ovaries are significantly enlarged and individual theca cells produce excessive amounts of androgens due, at least in part, to increased expression of several genes involved in steroidogenesis, including STAR, CYP11A1, HSD3B2 and CYP17A1 [2-4]. Among the above-listed genes, overexpression of CYP17A1, the key gene regulating androgen biosynthesis pathway, has been shown to play a prominent role in androgen excess in women with PCOS $[5,6]$.

Simvastatin belongs to the family of statins, competitive inhibitors of 3-hydroxy-3-methylglutaryl coenzyme A (HMG-CoA) reductase (HMGCR), the rate-limiting step of the mevalonate pathway. Thus, the effects of 
statins may be related to decreased availability of several downstream products of this pathway, such as substrates of isoprenylation: farnesyl pyrophosphate (FPP) and geranylgeranyl pyrophosphate (GGPP), as well as reduction of the availability of cholesterol. In addition to the beneficial effects of statins on cardiovascular diseases due to its cholesterol-lowering action [7,8], these agents have emerged over the past decade as promising novel treatments of endocrine disorders such as PCOS due to their anti-proliferative, androgen-lowering and anti-inflammatory properties. We have demonstrated that simvastatin reduces rat theca cell proliferation by mechanisms involving inhibition of isoprenylation $[9,10]$. Furthermore, our recent in vitro study has shown that simvastatin inhibits rat theca-interstitial steroidogenesis primarily by inhibiting Cyp17a1 mRNA expression, and this suppressive effect is mediated, at least in part, by decreased isoprenylation [10]. In clinical trials, we have shown that simvastatin treatment improves lipid profile, decreases systemic inflammation and reduces androgen levels in women with PCOS [11-13]. However, statins have potential adverse effects including a recently demonstrated risk of development of type 2 diabetes [14]. Hence, there is an urgent need to identify new agents that would either replace statins or potentiate their beneficial effects while reducing their adverse effects. We propose that resveratrol is such an agent. Notably, clinical use of resveratrol has been recently shown to reduce insulin resistance and likely decrease the risk of development of type 2 diabetes [15].

Resveratrol (trans-3,5,4' -trihydroxystilbene) is a natural polyphenol produced by several plants to protect them from pathogens such as bacteria and fungi. This phytoestrogen is found in grapes, nuts, berries and red wine and possesses a broad range of beneficial properties in different tissues, including anti-carcinogenic, cardioprotective, anti-inflammatory and anti-oxidant [16-19]. Previously, we found that resveratrol promotes apoptosis and inhibits proliferation in rat theca-interstitial cells, counteracting the anti-apoptotic and proliferative effects of insulin [20]. Additionally, we recently demonstrated that resveratrol reduces androgen production and Cyp17a1 mRNA gene expression, at least partly, via inhibition of Akt/PKB phosphorylation in rat thecainterstitial cells [21].

To date, only a few studies evaluated the potential beneficial effects of combined therapy using statin in conjunction with resveratrol. Penumathsa $e t$ al. demonstrated that simvastatin in combination with resveratrol is more cardioprotective than simvastatin alone using an ischemic rat heart model [22]. In our recent in vitro studies, resveratrol potentiated simvastatin-induced inhibition of rat theca-interstitial cell proliferation [23], as well as it augmented the inhibitory effects of simvastatin on cholesterol biosynthesis and HMGCR enzyme activity in primary cultures of human endometrial stromal cells [24].

In view of these considerations, we proposed that resveratrol may enhance simvastin-induced inhibition in steroidogenesis, exerting complementary actions on mechanisms regulating both gene expression and androgen production. In the present study we evaluated the effect of combining resveratrol and simvastatin treatments on rat thecainterstitial cell steroidogenesis. We demonstrated that resveratrol potentiated inhibitory effects of simvastatin on androstenedione and androsterone production by theca-interstitial cells. This suppressive effect correlated with profound inhibition in Cyp17a1 mRNA expression in the presence of a combination of resveratrol and simvastatin.

\section{Methods}

\section{Animals}

Female Sprague-Dawley rats were obtained at age 22 days from Charles River Laboratories (Wilmington, MA) and housed in an air-conditioned environment and a 12-h light/12-h dark cycle. All animals received standard rat chow and water ad libitum. At the age of 27, 28 and 29 days, the rats were injected with $17 \beta$-estradiol $(1 \mathrm{mg} /$ $0.3 \mathrm{ml}$ of sesame oil s.c.) to stimulate ovarian development and growth of antral follicles. Twenty-four hours after the last injection, the animals were anesthetized using ketamine and xylazine (i.p.) and euthanized by intracardiac perfusion using $0.9 \%$ saline. All treatments and procedures were carried out in accordance with accepted standards of human animal care as outlined in the National Institutes of Health Guide for the Care and Use of Laboratory Animals and a protocol approved by the Institutional Animal Care and Use Committee at the University of California, Davis.

\section{Cell culture and reagents}

The collection and purification of ovarian thecainterstitial cells were performed as described previously $[25,26]$. Briefly, the ovaries were removed from the animals and dissected free of oviducts and fat under a dissecting microscope. After a 60-minute collagenase digestion, theca-interstitial cells were purified using discontinuous Percoll gradient centrifugation. The cells were counted, and viability, as assessed by the trypan blue exclusion test, was routinely in the 90\%-95\% range. Theca-interstitial cells were incubated for 48 hours in 24-well fibronectin-coated plates at a density of 400,000 cells/well. The cultures were carried out at $37^{\circ} \mathrm{C}$ in an atmosphere of $5 \% \mathrm{CO}_{2}$ in humidified air in serum-free McCoy's 5A culture medium supplemented with $1 \%$ antibiotic/antimycotic mix, $0.1 \%$ bovine serum albumin and $2 \mathrm{mM} \mathrm{L}$-glutamine. The cells were incubated in the 
absence (control) or in the presence of simvastatin $(1 \mu \mathrm{M})$ and/or resveratrol $(3-10 \mu \mathrm{M})$. The concentrations of these compounds were selected based on our previous studies evaluating effects of simvastatin and resveratrol on ovarian theca-interstitial cell steroidogenesis [10,21]. All cultures were carried out in the presence of $\mathrm{LH}(5 \mathrm{ng} / \mathrm{ml})$. All above chemicals were purchased from Sigma Chemical Co. (St. Louis, MO) except for LH, which was obtained from the National Hormone \& Pituitary Program at the Harbor-UCLA Medical Center (Torrance, CA). Each experiment was repeated three times with four replicates in each experiment.

\section{Total RNA isolation and quantitative real-time PCR}

Total RNA was isolated using the MagMAX-96 Total RNA Isolation Kit (Applied Biosystems, Foster City, CA) and the KingFisher robot (Thermo Scientific, Vantaa, Finland). Reverse transcription of total RNA to cDNA was performed using High Capacity cDNA Reverse Transcription Kit for RT-PCR (Applied Biosystems, CA).

Quantitative real-time PCR reactions were performed in triplicate using the ABI 7300 Real-time PCR System (Applied Biosystems, Foster City, CA) and 2X SYBR Green PCR Master Mix (Applied Biosystem, Warrington, UK). Data were analyzed using SDS 1.4 software (Applied Biosystems). The relative amount of target mRNA was expressed as a ratio normalized to hypoxanthine phosphoribosyltransferase (Hprt). The primer sequences were as described in Table 1.

\section{Sample preparation and processing for quantification of steroids}

Each sample was directly assayed; the following extraction procedure was applied to each specimen. Each sample aliquot $(300 \mu \mathrm{l})$ was placed in a $2.0 \mathrm{ml}$ autosampler vial and spiked with $150 \mu \mathrm{l}$ of internal standard solution, i.e., androsteneione- $\mathrm{d} 7$ and testosterone- $\mathrm{d} 3$. Detection

Table 1 Primers for rat Hprt, Star, Cyp11a, Hsd3b1 and Cyp17a1

\begin{tabular}{ll}
\hline Gene & Primer sequence \\
\hline Hprt & Forward: 5'-TTG TTG GAT ATG CCC TTG ACT-3' \\
& Reverse: 5'-CCG CTG TCT TाT AGG CTT TG-3' \\
Star & Forward: 5'- GCC TGA GCA AAG CGG TGT C-3 \\
& Reverse: 5'- CTG GCG AAC TCT ATC TGG GTC TGT-3' \\
Cyp11a1 & Forward: 5'- GCT GGA AGG TGT AGC TCA GG-3' \\
& Reverse: 5'- CAC TGG TGT GGA ACA TCT GG-3' \\
Hsd3b1 & Forward: 5'- CCA GAA ACC AAG GAG GAA T-3' \\
& Reverse: 5'- CCA GAA ACC AAG GAG GAA T-3' \\
Cyp17a1 & Forward: 5'- ACT GAG GGT ATC GTG GAT GC-3' \\
& Reverse: 5'- CCG TCA GGC TGG AGA TAG AC-3'
\end{tabular}

and quantitation of all analytes was accomplished using selective reaction monitoring (SRM).

Androstenedione, androsterone, progesterone and the deuterated derivative of androsteneione- $\mathrm{d} 7$ were obtained from Steraloids (Newport, RI), whereas testosterone-d3 was obtained from Cerillient (Round Rock, TX). Acetonitrile and methanol were HPLC grade and obtained from Burdick and Jackson (Muskesgon, MI). Acetone, isopropanol, and ammonium hydroxide were Optima grade and obtained from Fisher (St. Louis, MO). Formic acid was ACS grade and obtained from EMD (Gibbstown, NJ).

\section{Mass spectrometry}

Simultaneous detection of androstenedione, androsterone and progesterone was achieved using a novel Turbulent Flow Chromatography HPLC-MS/MS method described in our previous study [21]. The response for androstenedione, androsterone, and progesterone were linear and gave correlation coefficients $\left(R^{2}\right) \geq 0.99$.

\section{Statistical analysis}

Statistical analysis was performed using JMP 9.0 software (SAS, Cary, NC). Data are presented as the mean \pm SEM. Means were compared by analysis of variance followed by post-hoc testing using Tukey's HSD Test. When appropriate, data were logarithmically transformed. A value of $\mathrm{P}<0.05$ was considered statistically significant.

\section{Results}

Effect of simvastatin and resveratrol on steroidogenic enzymes gene expression

To evaluate the effect of simvastatin alone and/or resveratrol on mRNA expression of the key genes regulating steroid biosynthesis pathway, theca-interstitial cells were cultured for $48 \mathrm{~h}$ in the absence or presence of simvastatin $(1 \mu \mathrm{M})$ and/or resveratrol $(3-10 \mu \mathrm{M})$. As presented in Figure 1A, resveratrol did not affect Star mRNA levels at any of the tested concentrations. Conversely, simvastatin induced a 1.6-fold increase in Star transcripts above the control level $(\mathrm{P}<0.001)$, whereas the addition of resveratrol to simvastatin-treated cultures had no significant effect on Star mRNA expression compared to the level attained with simvastatin alone, except for a modest decrease by $26 \%(\mathrm{P}<0.001)$ at the highest concentration.

In the same experiments, resveratrol at $10 \mu \mathrm{M}$ decreased Cyp11a1 and Hsd3b1 mRNA expression, respectively, by $38 \%$ and $42 \%$ (both at $\mathrm{P}<0.001$ ), whereas simvastatin did not have any significant effect on either Cyp11a1 or Hsd3b1 mRNA levels. In contrast, treatment of cells with simvastatin in combination with $10 \mu \mathrm{M}$ resveratrol decreased both Cyp11a1 and Hsd3b1 mRNA expression, respectively, by $55 \%$ and $43 \%$ (both at $\mathrm{P}$ $<0.001$ ) below the level observed with simvastatin alone (Figure 1B-C). Notably, in the presence of simvastatin, 


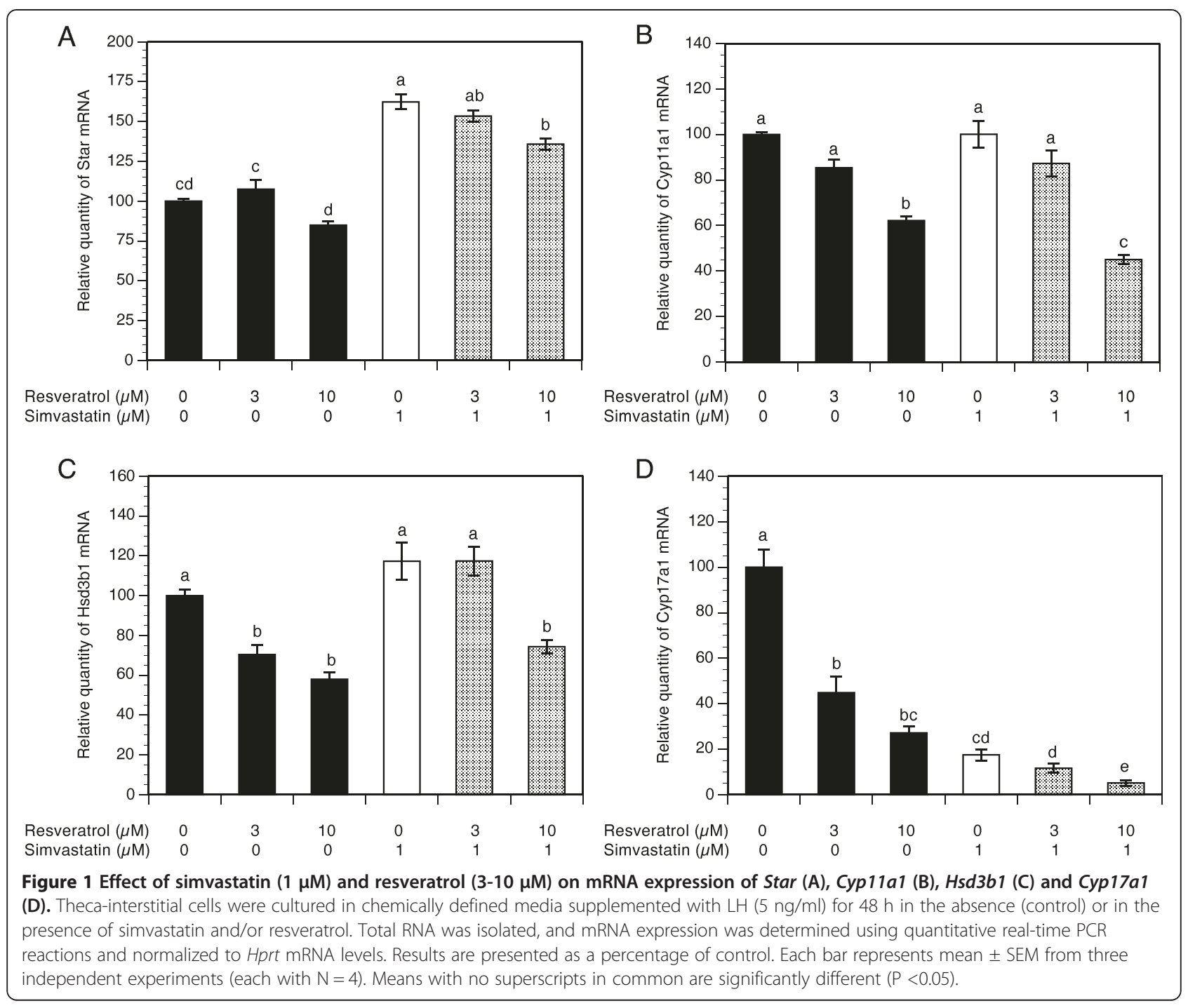

reduction of Cyp11a1 mRNA was greater than that achieved by resveratrol alone, whereas simvastatin had no additive effect on resveratrol-induced decline of Hsd3b1 mRNA.

The most profound resveratrol-induced inhibitory effect on mRNA expression was found in Cyp17a1; resveratrol at the highest concentration $(10 \mu \mathrm{M})$ reduced Cyp17a1 mRNA levels by $73 \%(\mathrm{P}<0.001)$. Exposure of cells to simvastatin treatment decreased Cyp17a1 transcripts by $82 \%(\mathrm{P}<0.001)$ and this simvastatin-induced inhibitory effect on Cyp17a1 mRNA expression was further enhanced to $95 \%(\mathrm{P}<0.001)$ in the presence of $10 \mu \mathrm{M}$ resveratrol (Figure 1D).

\section{Effect of simvastatin and resveratrol on steroid production}

To determine the effect of simvastatin alone and/or resveratrol on steroid production, levels of progesterone, androstenedione and androsterone were evaluated in spent media using liquid chromatography-mass spectrometry. To account for both simvastatin and resveratrol potential effects on the cell number, the production of steroids was calculated per unit of protein in each individual culture well and then expressed as percentage of control cultures. Steroid levels are presented as percentage of control in order to facilitate combining of the results of three separate experiments whereby in each experiment levels of steroids in control cultures served as normalizing references. The levels of steroids in control cultures were as follows: progesterone level ranged from $5,328 \mathrm{pg} / \mathrm{mg}$ to $18,532 \mathrm{pg} / \mathrm{mg}$ (Mean $=10,484 \mathrm{pg} /$ $\mathrm{mg}$ ), androstenedione level ranged from $392 \mathrm{pg} / \mathrm{mg}$ to $3,112 \mathrm{pg} / \mathrm{mg}$ (Mean $=1,200 \mathrm{pg} / \mathrm{mg}$ ) and androsterone level ranged from $657 \mathrm{pg} / \mathrm{mg}$ to $26,786 \mathrm{pg} / \mathrm{mg}$ (Mean = $11,053 \mathrm{pg} / \mathrm{mg}$ ).

As presented in Figure 2A, resveratrol did not affect progesterone production except for a slight decrease by $20 \%(\mathrm{P}<0.01)$ at a concentration of $3 \mu \mathrm{M}$, whereas 


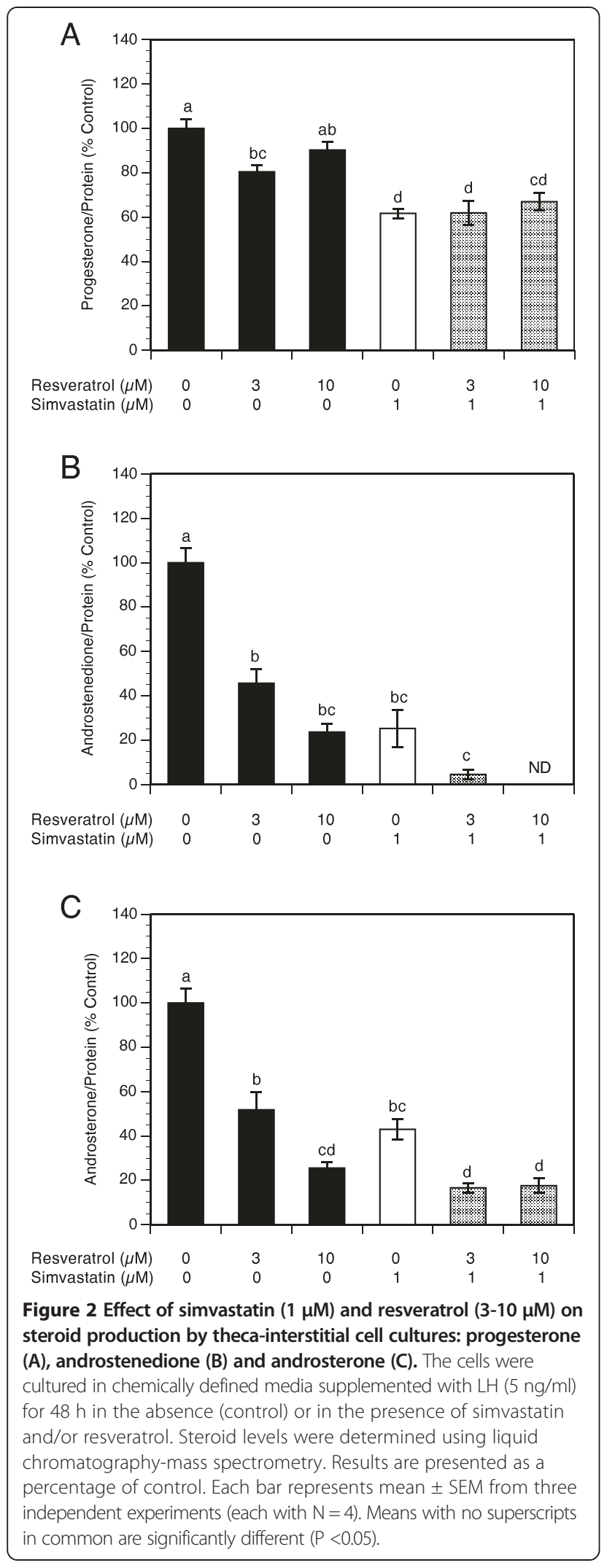

simvastatin significantly decreased progesterone production by $38 \%$ ( $\mathrm{P}<0.001)$. The addition of resveratrol to simvastatin-treated cultures had no significant effect compared to the level observed with simvastatin alone at any of the concentrations tested.

With regard to androgen production, resveratrol induced a concentration-dependent inhibitory effect: at the highest concentration $(10 \mu \mathrm{M})$ androstenedione levels decreased by $76 \%(\mathrm{P}<0.01)$. Simvastatin alone inhibited androstenedione production by $83 \%(\mathrm{P}<0.001)$ and this effect was enhanced by the addition of resveratrol whereby a combination of simvastatin and resveratrol at $10 \mu \mathrm{M}$ reduced androstenedione to non-detectable levels (Figure 2B).

In a similar fashion, resveratrol induced a concentrationdependent decrease in androsterone levels by up to $76 \%$ at $10 \mu \mathrm{M}$ resveratrol. Simvastatin decreased androsterone production by $57 \%$ ( $\mathrm{P}<0.001)$, whereas the addition of $10 \mu \mathrm{M}$ resveratrol potentiated simvastatin-induced inhibition of androsterone levels by additional 25\% ( $\mathrm{P}<0.001)$ compared to the level attained with simvastatin alone (Figure 2C).

\section{Discussion}

This study demonstrates that in cultures of thecainterstitial cells: 1 ) both resveratrol and simvastatin inhibit androgen production; 2) the simvastatin-induced decrease in androgen levels is enhanced by the addition of resveratrol; 3) the combination of simvastatin and resveratrol decreases mRNA levels of key steroidogenic genes compared to simvastatin alone with particularly profound inhibition of Cyp17a1 mRNA expression.

The novel finding of the present study is the potentiating effect of resveratrol on simvastatin-induced inhibition of steroidogenesis indicating that these compounds may exert complementary actions on mechanisms regulating ovarian steroidogenesis. The mevalonate pathway is an important cellular metabolic pathway that provides cells with diverse molecules such as cholesterol and substrates of isoprenylation: farnesyl pyrophosphate (FPP) and geranylgeranyl pyrophosphate (GGPP), which play crucial roles in cell functions [23]. Isoprenylation consists of the attachment of lipophilic FPP (farnesylation) or GGPP (geranylation) to the carboxyl terminus of proteins, regulating the function of several small guanine triphosphatases, such as Ras. Once this membrane associated GTPase has been activated, it recruits the serine/threonine kinase Raf and facilitate its activation. Then, Raf phosphorylates and stimulates the downstream kinase MEK, which in turn exhibits a serine/threonine and tyrosine kinase activity, resulting in the phosphorylation and activation of the extracellular signal-regulated kinase $1 / 2$ (Erk1/2). The Ras-Raf-Erk $1 / 2$ signaling pathway regulates a large array of intracellular events, such as proliferation, differentiation, stress response, apoptosis and steroidogenesis. It 
should be noted, however, that the role of the Erk $1 / 2$ signaling pathway in steroidogenesis is, as yet, poorly understood, due to conflicting reports demonstrating stimulation, inhibition or no effect in different steroidogenic cells $[27,28]$. The inhibitory effect of statins on the mevalonate pathway by inhibiting HMGCR, the rate limiting step of cholesterol synthesis, leads to decreased availability of several downstream products of the pathway, including cholesterol and isoprenoids. We speculate that simvastatin inhibits theca-cell steroidogenesis by inhibiting the isoprenylation of Ras and its subsequent activity on the Ras-Raf-Erk1/2 signaling pathway. Consistent with the above considerations, our previous in vitro study demonstrated that simvastatin-induced inhibitory effect on theca-interstitial cell steroidogenesis is mediated, at least in part, by mechanisms involving decreased isoprenylation $[9,10]$. Furthermore, we previously demonstrated that another statin, mevastatin, inhibits theca-interstitial cell proliferation by selective inhibition of basal and insulin-induced activity of the Erk1/2 pathway [29].

To date, little is known regarding the role that resveratrol plays in the modulation of the mevalonate pathway. In vivo studies have shown that resveratrol reduces hepatic HMGCR expression as well as activity in hamsters and mice [30,31]. In our recent in vitro study resveratrol inhibited both HMGCR expression and activity in rat thecainterstitial cells [23]. These effects may be cell-specific since resveratrol had no significant effect on cholesterol synthesis and HMGCR activity in a study of rat hepatocytes [32].

Effects of resveratrol on the mevalonate pathway may be relevant to some and not to other effects on the function of theca-interstitial cells. We have shown that resveratrolinduced inhibition of proliferation of rat theca-interstitial cells is due, at least partly, to reduced isoprenylation [23]. However, in our recent study on effects of resveratrol on steroidogenesis, we found that the inhibitory effects were mediated by mechanisms independent of isoprenylation [21]. Indeed, in the same study we demonstrated that resveratrol decreases phosphorylation of Akt/protein kinase $B(P K B)$, suggesting that selective inhibition of Akt/PKB pathway activity may be involved in resveratrol-induced effects on theca cell steroidogenesis.

Thus, a combination of simvastatin and resveratrol may be blocking separate crucial cell signaling pathways, such as Ras-Raf-Erk1/2 and Akt/PKB, and hence may exert inhibitory and cumulative effects on inhibition of androgen production. Previously, these pathways have been shown to be involved in the regulation of ovarian functions such as gene expression of key steroidogenic genes [33,34]. Furthermore, cross talk between the Akt/PKB and Erk1/2 pathways had been previously described in several cell types [35]. We speculate that these mechanisms of action of statin and resveratrol on key signal transduction pathways involved in steroidogenesis may account for the potentiating effect of resveratrol on simvastatin-induced inhibition of theca-interstitial cell steroidogenesis.

One potential concern regarding resveratrol pertains to its low bioavailability. In the present study, resveratrol actions were evaluated at doses ranging from 3 to $10 \mu \mathrm{M}$. These doses are comparable to those used in previous studies, whereby resveratrol inhibited both proliferation and steroidogenesis at concentrations in the range from 1 to $400 \mu \mathrm{M}[21,36,37]$. Studies on animal models and clinical trials indicate that these concentrations are likely to be clinically relevant, since the bioavailability of resveratrol in both human and rodent models is in the micromolar range $[37,38]$. For example, in rodents, resveratrol treatment led to its detection in multiple organs with the highest concentration in the kidney $(30 \mu \mathrm{M})$ and liver $(25 \mu \mathrm{M})$ [39], whereas the concentration of trans-resveratrol in the plasma ranged from 6 to $78.1 \mu \mathrm{M}$ [40]. In humans, in a phase I study of oral resveratrol (single doses of $0.5,1,2.5$, or $5 \mathrm{~g}$ ) conducted in 10 healthy volunteers, peak plasma levels of resveratrol at the highest dose were $2.4 \mu \mathrm{M}$, whereas peak levels of resveratrol metabolites: monoglucuronides and resveratrol-3-sulfate were 3- to 8-fold higher [41]. Therefore, the concentration of resveratrol required to inhibit steroidogenesis in the present study agrees with those used in other in vitro studies, indicating that resveratrol at pharmacological concentrations may be effective in reducing steroidogenesis in rat theca-interstitial cells.

In the present study we have demonstrated that a combination treatment with resveratrol and simvastatin is more effective in decreasing mRNA expression of the several genes regulating the steroid biosynthesis pathway compared to treatment using simvastatin alone. Notably, the extent of inhibition in Cyp17a1 mRNA expression induced by combination therapy was more profound compared to the effects on other genes involved in the steroidogenic function of theca-interstitial cells. Interestingly, previous studies of other biological systems have shown that resveratrol directly inhibits expression of several members of the family of human recombinant cytochromes acting as drug-metabolizing enzymes, such as CYP1A1, CYP1A2 and CYP1B1 [42-44]. A suppression of Cyp17a1 mRNA expression, the rate-limiting step in the androgen biosynthesis pathway, decreases the conversion of progesterone into androstenedione, leading to accumulation of progesterone and decreased biosynthesis of androgens. However, in the present study the combination treatment with resveratrol and simvastatin dramatically decreased androstenedione and androsterone production, whereas levels of progesterone did not change compared to cultures with simvastatin alone. We propose that despite profound reduction of Cyp17a1 mRNA expression, progesterone levels did not increase due to a concomitant modest decrease in mRNA expression of other genes 
involved in progesterone production (Star, Cyp11a1 and Hsd3b1).

These findings may be of clinical relevance and provide a rationale for the use of a combination therapy with resveratrol and statins in treatment of hyperandrogenic conditions such as PCOS. Notably, the presently observed effects of resveratrol in combination with statin are likely to correct the key enzymatic aberrations of steroidogenesis by theca cells in women with PCOS. These aberrations include increased expression of genes regulating the androgen biosynthesis pathway including STAR, CYP11A1, HSD3B2 and CYP17A1 [2-4,45] as well as overexpression of Cyp17a1 and increased activity of $17 \alpha$-hydroxylase/17, 20-lyase which contribute to increased circulating levels of 17-hydroxyprogesterone in response to gonadrotropin stimulation $[6,46]$.

\section{Conclusion}

In conclusion, our results demonstrate for the first time that resveratrol potentiates the effects of simvastatin on inhibition of rat theca-interstitial cell androgen production. These observations may be relevant to the development of novel therapies aimed to reduce ovarian hyperandrogenism in women with PCOS.

\section{Abbreviations \\ Akt/PKB: Serine-threonine kinase (Akt)/protein kinase $B_{i}$ \\ CDNA: complementary desoxirribonucleic acid; CYP11A1: Gene encoding cholesterol side chain cleavage cytochrome P450sc; CYP17A1: Gene encoding 17a-hydroxylase/C17-20 lyase cytochrome P450c17; ERK: Extracellular-signal regulated kinase; FPP: Farnesyl pyrophosphate; GGPP: Geranylgeranyl pyrophosphate; HMG-CoA: 3-hydroxy-3-methylglutaryl coenzyme A; HMGCR: 3-hydroxy-3-methylglutaryl coenzyme A reductase; HPRT: Hypoxanthine phosphoribosyltransferase; HSD3B1: Gene encoding 3ß-hydroxysteroid dehydrogenase in the rat; HSD3B2: Gene encoding 3ß-hydroxysteroid dehydrogenase in human; MEK: MAPKJERK kinase; mRNA: messenger ribonucleic acid; LC-MS: Liquid cromatography-mass spectrometry; LH: Luteinizing hormone; RT-PCR: Reverse transcription polymerase chain reaction; StAR: Gene encoding steroidogenic acute regulatory protein; PCOS: Polycystic ovary syndrome.}

\section{Competing interests}

The authors declare that they have no competing interests.

\section{Authors' contributions}

IO planned and ran the experiments, conducted statistical analysis and wrote the manuscript. JAV, DHW, ABC, AS and SDS assisted with experiments and reviewed the manuscript. AJD planned the experiments, supervised and contributed to data interpretation and writing the manuscript. All authors read and approved the final manuscript.

\section{Acknowledgements}

This study was supported by grant R01-HD050656 from the Eunice Kennedy Shriver National Institute of Child Health and Human Development (to AJD).

\section{Author details}

'Department of Obstetrics and Gynecology, School of Medicine, University of California, Davis, CA 95616, USA. ${ }^{2}$ VVI-Madrid, Madrid, Spain. ${ }^{3}$ Department of Gynecology, Obstetrics and Gynecological Oncology, Karol Marcinkowski University of Medical Sciences, 60-701 Poznan, Poland. ${ }^{4}$ Department of Obstetrics and Gynecology, University of Pennsylvania, Philadelphia, PA 19104, USA. ${ }^{5}$ Department of Molecular Biosciences, University of California, Davis, CA 95616, USA
Received: 10 October 2013 Accepted: 2 February 2014

Published: 13 February 2014

\section{References}

1. Parrott JA, Skinner MK: Developmental and hormonal regulation of keratinocyte growth factor expression and action in the ovarian follicle. Endocrinology 1998, 139:228-235.

2. McAllister JM, Kerin JF, Trant JM, Estabrook RW, Mason JI, Waterman MR, Simpson ER: Regulation of cholesterol side-chain cleavage and 17 alpha-hydroxylase/lyase activities in proliferating human theca interna cells in long term monolayer culture. Endocrinology 1989, 125:1959-1966.

3. Wickenheisser JK, Nelson-Degrave VL, McAllister JM: Dysregulation of cytochrome P450 17alpha-hydroxylase messenger ribonucleic acid stability in theca cells isolated from women with polycystic ovary syndrome. J Clin Endocrinol Metab 2005, 90:1720-1727.

4. Jakimiuk AJ, Weitsman SR, Navab A, Magoffin DA: Luteinizing hormone receptor, steroidogenesis acute regulatory protein, and steroidogenic enzyme messenger ribonucleic acids are overexpressed in thecal and granulosa cells from polycystic ovaries. J Clin Endocrinol Metab 2001, 86:1318-1323.

5. Wickenheisser JK, Quinn PG, Nelson VL, Legro RS, Strauss JF 3rd, McAllister $J M$ : Differential activity of the cytochrome P450 17alpha-hydroxylase and steroidogenic acute regulatory protein gene promoters in normal and polycystic ovary syndrome theca cells. J Clin Endocrinol Metab 2000, 85:2304-2311

6. Wachs DS, Coffler MS, Malcom PJ, Shimasaki S, Chang RJ: Increased androgen response to follicle-stimulating hormone administration in women with polycystic ovary syndrome. J Clin Endocrinol Metab 2008, 93:1827-1833

7. Ravingerova T, Adameova A, Kelly T, Antonopoulou E, Pancza D, Ondrejcakova M, Khandelwal VK, Carnicka S, Lazou A: Changes in PPAR gene expression and myocardial tolerance to ischaemia: relevance to pleiotropic effects of statins. Can J Physiol Pharmacol 2009, 87:1028-1036.

8. Wolfrum S, Dendorfer A, Schutt M, Weidtmann B, Heep A, Tempel K, Klein HH, Dominiak P, Richardt G: Simvastatin acutely reduces myocardial reperfusion injury in vivo by activating the phosphatidylinositide 3-kinase/Akt pathway. J Cardiovasc Pharmacol 2004, 44:348-355.

9. Rzepczynska IJ, Piotrowski PC, Wong DH, Cress AB, Villanueva J, Duleba AJ: Role of isoprenylation in simvastatin-induced inhibition of ovarian theca-interstitial growth in the rat. Biol Reprod 2009, 81:850-855.

10. Ortega I, Cress AB, Wong DH, Villanueva JA, Sokalska A, Moeller BC, Stanley SD, Duleba AJ: Simvastatin reduces steroidogenesis by inhibiting Cyp17a1 gene expression in rat ovarian theca-interstitial cells. Biol Reprod 2012, 86:1-9.

11. Banaszewska B, Pawelczyk L, Spaczynski RZ, Duleba AJ: Effects of simvastatin and metformin on polycystic ovary syndrome after six months of treatment. / Clin Endocrinol Metab 2011, 96:3493-3501.

12. Banaszewska B, Pawelczyk L, Spaczynski RZ, Duleba AJ: Comparison of simvastatin and metformin in treatment of polycystic ovary syndrome: prospective randomized trial. J Clin Endocrinol Metab 2009, 94:4938-4945.

13. Banaszewska B, Pawelczyk L, Spaczynski RZ, Dziura J, Duleba AJ: Effects of simvastatin and oral contraceptive agent on polycystic ovary syndrome: prospective, randomized, crossover trial. J Clin Endocrinol Metab 2007, 92:456-461.

14. Culver AL, Ockene IS, Balasubramanian R, Olendzki BC, Sepavich DM Wactawski-Wende J, Manson JE, Qiao Y, Liu S, Merriam PA, Rahilly-Tierny C, Thomas F, Berger JS, Ockene JK, Curb JD, Ma Y: Statin use and risk of diabetes mellitus in postmenopausal women in the women's health initiative. Arch Intern Med 2012, 172:144-152.

15. Crandall JP, Oram V, Trandafirescu G, Reid M, Kishore P, Hawkins M, Cohen HW, Barzilai N: Pilot study of resveratrol in older adults with impaired glucose tolerance. J Gerontol A Biol Sci Med Sci 2012, 67:1307-1312.

16. Nambiar D, Rajamani P, Singh RP: Effects of phytochemicals on ionization radiation-mediated carcinogenesis and cancer therapy. Mutat Res 2011, 728:139-157.

17. Gutierrez-Perez A, Cortes-Rojo C, Noriega-Cisneros R, Calderon-Cortes E, Manzo-Avalos S, Clemente-Guerrero M, Godinez-Hernandez D, Boldogh I, Saavedra-Molina A: Protective effects of resveratrol on calcium-induced oxidative stress in rat heart mitochondria. J Bioenerg Biomembr 2011, 43:101-107.

18. Xuzhu G, Komai-Koma M, Leung BP, Howe HS, McSharry C, McInnes IB, Xu D: Resveratrol modulates murine collagen-induced arthritis by inhibiting Th17 and B-cell function. Ann Rheum Dis 2012, 71:129-135. 
19. Fabre KM, Saito K, Degraff W, Sowers AL, Thetford A, Cook JA, Krishna MC, Mitchell JB: The effects of resveratrol and selected metabolites on the radiation and antioxidant response. Cancer Biol Ther 2011, 12:915-923.

20. Wong $D H$, Villanueva JA, Cress $A B$, Duleba AJ: Effects of resveratrol on proliferation and apoptosis in rat ovarian theca-interstitial cells. Mol Hum Reprod 2010, 16:251-259.

21. Ortega I, Villanueva JA, Wong DH, Cress AB, Sokalska A, Stanley SD, Duleba AJ: Resveratrol reduces steroidogenesis in rat ovarian theca-interstitial cells: the role of inhibition of Akt/PKB signaling pathway. Endocrinology 2012, 153:4019-4029.

22. Penumathsa SV, Thirunavukkarasu M, Koneru S, Juhasz B, Zhan L, Pant R, Menon VP, Otani H, Maulik N: Statin and resveratrol in combination induces cardioprotection against myocardial infarction in hypercholesterolemic rat. J Mol Cell Cardio/ 2007, 42:508-516.

23. Wong DH, Villanueva JA, Cress AB, Sokalska A, Ortega I, Duleba AJ: Resveratrol inhibits the mevalonate pathway and potentiates the antiproliferative effects of simvastatin in rat theca-interstitial cells. Fertil Steril 2011, 96:1252-1258

24. Villanueva JA, Sokalska A, Cress AB, Ortega I, Bruner-Tran KL, Osteen KG, Duleba AJ: Resveratrol potentiates effect of simvastatin on inhibition of mevalonate pathway in human endometrial stromal cells. J Clin Endocrinol Metab 2013, 98:E455-462

25. Magoffin DA, Erickson GF: Purification of ovarian theca-interstitial cells by density gradient centrifugation. Endocrinology 1988, 122:2345-2347.

26. Duleba AJ, Spaczynski RZ, Olive DL, Behrman HR: Effects of insulin and insulin-like growth factors on proliferation of rat ovarian theca-interstitial cells. Biol Reprod 1997, 56:891-897.

27. Manna PR, Stocco DM: The role of specific mitogen-activated protein kinase signaling cascades in the regulation of steroidogenesis. J Signal Transduct 2011, 2011:821615.

28. Stocco DM, Wang $X$, Jo Y, Manna PR: Multiple signaling pathways regulating steroidogenesis and steroidogenic acute regulatory protein expression: more complicated than we thought. Mol Endocrinol 2005, 19:2647-2659

29. Kwintkiewicz J, Foyouzi N, Piotrowski P, Rzepczynska I, Duleba AJ: Mevastatin inhibits proliferation of rat ovarian theca-interstitial cells by blocking the mitogen-activated protein kinase pathway. Fertil Steril 2006, 86:1053-1058

30. Do GM, Kwon EY, Kim HJ, Jeon SM, Ha TY, Park T, Choi MS: Long-term effects of resveratrol supplementation on suppression of atherogenic lesion formation and cholesterol synthesis in apo E-deficient mice. Biochem Biophys Res Commun 2008, 374:55-59.

31. Cho IJ, Ahn JY, Kim S, Choi MS, Ha TY: Resveratrol attenuates the expression of HMG-CoA reductase mRNA in hamsters. Biochem Biophys Res Commun 2008, 367:190-194.

32. Gnoni GV, Paglialonga G: Resveratrol inhibits fatty acid and triacylglycerol synthesis in rat hepatocytes. European Journal of Clinical Investigation 2009, 39:211-218.

33. Fukuda S, Orisaka M, Tajima K, Hattori K, Kotsuji F: Luteinizing hormone-induced Akt phosphorylation and androgen production are modulated by MAP Kinase in bovine theca cells. Journal Of Ovarian Research 2009, 2:17.

34. Paul S, Kundu S, Pramanick K, Bandyopadhyay A, Mukherjee D: Regulation of ovarian steroidogenesis in vitro by gonadotropin in common carp Cyprinus carpio: interaction between calcium- and adenylate cyclase-dependent pathways and involvement of ERK signaling cascade. $\mathrm{J}$ Mol Endocrinol 2010, 45:207-218.

35. De Luca A, Maiello MR, D'Alessio A, Pergameno M, Normanno N: The RAS/RAF/MEK/ERK and the PI3K/AKT signalling pathways: role in cancer pathogenesis and implications for therapeutic approaches. Expert Opin Ther Targets 2012, 16(Suppl 2):S17-27.

36. Chen YC, Nagpal ML, Stocco DM, Lin T: Effects of genistein, resveratrol, and quercetin on steroidogenesis and proliferation of MA-10 mouse Leydig tumor cells. J Endocrinol 2007, 192:527-537.

37. van Ginkel PR, Sareen D, Subramanian L, Walker Q, Darjatmoko SR Lindstrom MJ, Kulkarni A, Albert DM, Polans AS: Resveratrol inhibits tumor growth of human neuroblastoma and mediates apoptosis by directly targeting mitochondria. Clin Cancer Res 2007, 13:5162-5169.

38. Walle $T$, Hsieh F, DeLegge MH, Oatis JE Jr, Walle UK: High absorption but very low bioavailability of oral resveratrol in humans. Drug Metabolism And Disposition: The Biological Fate Of Chemicals 2004, 32:1377-1382
39. Vitrac X, Desmouliere A, Brouillaud B, Krisa S, Deffieux G, Barthe N, Rosenbaum J, Merillon JM: Distribution of [14C]-trans-resveratrol, a cancer chemopreventive polyphenol, in mouse tissues after oral administration. Life Sci 2003, 72:2219-2233.

40. Juan ME, Maijo M, Planas JM: Quantification of trans-resveratrol and its metabolites in rat plasma and tissues by HPLC. J Pharm Biomed Anal 2010, 51:391-398.

41. Boocock DJ, Faust GE, Patel KR, Schinas AM, Brown VA, Ducharme MP, Booth TD, Crowell JA, Perloff M, Gescher AJ, Steward WP, Brenner DA: Phase I dose escalation pharmacokinetic study in healthy volunteers of resveratrol, a potential cancer chemopreventive agent. Cancer Epidemiol Biomarkers Prev 2007, 16:1246-1252.

42. Beedanagari SR, Bebenek I, Bui P, Hankinson O: Resveratrol inhibits dioxin-induced expression of human CYP1A1 and CYP1B1 by inhibiting recruitment of the aryl hydrocarbon receptor complex and RNA polymerase II to the regulatory regions of the corresponding genes. Toxicol Sci 2009, 110:61-67.

43. Chen ZH, Hurh YJ, Na HK, Kim JH, Chun YJ, Kim DH, Kang KS, Cho MH, Surh YJ: Resveratrol inhibits TCDD-induced expression of CYP1A1 and CYP1B1 and catechol estrogen-mediated oxidative DNA damage in cultured human mammary epithelial cells. Carcinogenesis 2004, 25:2005-2013.

44. Ciolino HP, Yeh GC: Inhibition of aryl hydrocarbon-induced cytochrome P-450 1A1 enzyme activity and CYP1A1 expression by resveratrol. Mol Pharmacol 1999, 56:760-767.

45. Daneshmand S, Weitsman SR, Navab A, Jakimiuk AJ, Magoffin DA: Overexpression of theca-cell messenger RNA in polycystic ovary syndrome does not correlate with polymorphisms in the cholesterol side-chain cleavage and 17alpha-hydroxylase/C(17-20) lyase promoters. Fertil Steril 2002, 77:274-280.

46. Rosenfield RL, Barnes RB, Ehrmann DA: Studies of the nature of 17-hydroxyprogesterone hyperresonsiveness to gonadotropin-releasing hormone agonist challenge in functional ovarian hyperandrogenism. J Clin Endocrinol Metab 1994, 79:1686-1692.

doi:10.1186/1757-2215-7-21

Cite this article as: Ortega et al:: Resveratrol potentiates effects of simvastatin on inhibition of rat ovarian theca-interstitial cells steroidogenesis. Journal of Ovarian Research 2014 7:21.

\section{Submit your next manuscript to BioMed Central and take full advantage of:}

- Convenient online submission

- Thorough peer review

- No space constraints or color figure charges

- Immediate publication on acceptance

- Inclusion in PubMed, CAS, Scopus and Google Scholar

- Research which is freely available for redistribution 